$\overline{\text { ARTÍCULOS }}$ 



\section{REFLEXIÓN SOBRE LA DIMENSIÓN ESPECTATORIAL DE LAS PELÍCULAS AFRICANAS: O CÓMO LOS CINES AFRICANOS PIENSAN DE OTRA MANERA EN SUS PÚBLICOS ${ }^{1}$}

Reflection About the Spectatorial Dimension of African Films: or How African Cinemas Think of Their Public Otherwise

MAHOMED BAMBA ${ }^{\mathrm{a}}$ Universidad Federal de Bahía DOI: http://dx.doi.org/10.15366/secuencias2015.41.001

\section{RESUMEN}

Este artículo investiga la construcción textual del espectador en varias películas africanas. Un espectador que aparece inscrito «en filigrana» a través de los gestos enunciativos y estrategias paratextuales de cineastas que siguen la lógica poética del cine de autor. Es a través del análisis de estas estrategias estilísticas y narrativas, de los recursos simbólicos utilizados, de las huellas metadiscursivas presentes en los textos, como se puede averiguar, más allá de las intenciones expresadas por los propios cineastas, o de los resultados en taquilla, en qué medida los autores han pensado o no en los públicos africanos, y si se dirigen exclusivamente a ellos.

Palabras clave: relato, sistema textual, paratexto, espectador implícito, semiopragmática, griot, cine de autor.

\section{ABSTRACT}

This article explores the textual construction of the spectator in various African films. A spectator that seems to be registered as a 'watermark' through the expository gestures and paratextual strategies of filmmakers that follow the poetic logic of auteur cinema. It is through the analysis of these stylistic and narrative strategies, of the symbolic resources used, and of the metadiscursive traces present in the texts, that the extent to which the authors have taken into consideration the African audience, and whether or not they are aiming exclusively at them, can be explored - even in terms beyond those directly expressed by the filmmakers themselves.

Keywords: story, textual system, paratext, implicit spectator, semio-pragmatics, griot, auteur cinema

[a] МАномеd ВАмва, nacido en Costa de Marfil, ha fallecido inesperadamente durante la elaboración de este monográfico. Enseñaba en la Facultad de Comunicación de la Universidad Federal de Bahía (Brasil). Como investigador, estaba especializado en Historia de los cines africanos y las diásporas, Teorías de la Recepción, Cine e identidades plurales, Teorías del cine transnacional, y Semiología y narratología fílmicas. Fue editor, junto a Alessandra Meleiro de Filmes da África e da Diáspora. Objetos de discursos (EDUFBA: 2012). Acaba de publicarse póstumamente su libro O Legível e o Visível no Cinema: O Signo Escrito na Construção e na Leitura Fílmicas (Appris, 2015). 


\section{Introducción}

«Solo el cine popular se toma a los espectadores africanos en serio $y$, por lo tanto, representa el futuro del lenguaje cinematográfico en África. Paradójicamente, a pesar de que estas películas todavía no disfrutan de los espectadores que se merecen, constituyen el verdadero comienzo del cine africano para los africanos» ${ }^{1}$

Como en el caso de otras cinematografías del world cinema, la cuestión del público siempre ha estado presente en los debates y estudios críticos sobre los cines africanos. Tras los antropólogos e historiadores que se cuestionaron muy pronto las relaciones simbólicas entre las poblaciones africanas y la imagen fílmica en general, son ahora los propios cineastas africanos los que han hecho de los «públicos africanos» el objeto de sus preocupaciones ${ }^{2}$. A diferencia de una película de ficción por ejemplo, un documental africano puede mostrar su intención de ir al encuentro «físico» del público que consume el cine en África. Es a esta búsqueda a la que se lanza Jean-Marie Teno en Lieux Saints (2009). Son las mujeres, los hombres y los niños en su relación con el arte y el cine lo que parece interesar al autor. Son por tanto, los espectadores cinematográficos africanos de los cineclubs los que se expresan en este documental de Teno. Los aísla en los lugares que ocupan, es decir en dichos cineclubs, pero también explora su universo, intentando comprender su imaginario, así como sus modos de consumo y apropiación de películas y de productos audiovisuales en un mun do que se dice globalizado. Pero desde un punto de vista más teórico y siguiendo una perspectiva pragmática, la cuestión del «público» en los cines africanos puede plantearse en términos de «sujeto espectador» y de implicación espectatorial en la economía narrativa de la ficción. En otras palabras, sería una forma de buscar las huellas de la recepción en el texto fílmico, de abordar la cuestión del espectador a partir de los gestos enunciativos propios de cada película (tomada individualmente) o de una categoría de películas (que forma un sistema textual particular dentro del vasto campo de los cines africanos). Estos son los pasos que me propongo seguir en este artículo.

Las películas africanas (como toda película), además de intentar dar una representación realista y, en ocasiones crítica de África y de sus culturas, también hacen vivir al espectador una experiencia discursiva y narrativa: todo está urdido para atraer la atención perceptiva sobre la trama de la historia narrada, pero también sobre la estructura del relato. Es por lo tanto, a través de la experiencia de la enunciación, como también podemos encontrar los rastros y las figuras del espectador de forma implícita en las películas africanas. Algunos cineastas africanos, siguiendo la lógica de la poética del cine moderno o del cine de autor, van todavía más lejos: inscriben implícitamente su intención de «significar» de otro modo la presencia del espectador en su trabajo de puesta en escena, mediante guiños, alusiones a otras películas, con miradas (in)directas y con referencias metafílmicas. En estas películas de autor se crea un efecto de espejo que vuelve a llevar al espectador implícito a la imagen de los otros espec-

[1] Manthia Diawara, African Film: New Forms of Aesthetic and Politics (Munich/Berlin, Prestel Verlag, 2010), p. 145.

[2] Aunque es verdad que algunos cineastas africanos han sido acusados con razón o sin ella de hacer "películas de y para festivales», paradójicamente los críticos de cine no cesan de hacer del didactismo uno de los rasgos de las primeras películas africanas. El mismo Ousmane Sembène anunciaba, por ejemplo, en una emisión de televisión, su deseo de ver todas sus películas dobladas a varias lenguas africanas, con el fin de que llegaran al mayor número posible de espectadores en cada rincón de ese continente. 
[3] Con el que, por otra parte, un cineasta africano podría intercambiar algunas palabras durante un debate, por ejemplo, en un festival.

[4] Mientras que Christian Metz ve en las huellas de este proceso textual una dimensión constitutiva de lo que él llama «enunciación impersonal» (1991), Francesco Casetti, los interpreta al contrario, como formas de interpelación y de mirada directa al espectador (1998).

[5] Pienso, sobre todo, en la noción de «cooperación» en el acto de lectura según ha sido desarrollada por Umberto Eco y otros teóricos de la semiótica de la lectura y de la interpretación a través de las categorías de «lector modelo» $\mathrm{y}$ «lector implícito». Umberto Eco, Lector in fabula: le rôle du lecteur, ou la coopération interprétative dans les textes narratifs (Paris, Grasset, 1985).

[6] Aunque Casetti haga una distinción entre «interpelación» $\mathrm{y}$ «mirada» en la película, utilizaré aquí estas dos nociones como sinónimas.

[7] Me refiero, por supuesto, a un cierto «cine de autor» africano. tadores vistos en la pantalla. No es pues el espectador empírico de carne y hueso $^{3}$ el que me interesa. Tampoco es el público real que ha ido a ver una película africana en una sala de cine o en un festival mi objeto de estudio. Mi intención concierne, ante todo, al espectador de la película africana según me permiten construirlo por inferencia y por deducción el texto y el paratexto fílmicos. Es pues, por las brechas de la enunciación y de la reflexividad cinematográficas por las que avanzaré para interrogar a las relaciones semióticas, metafóricas y simbólicas de los cines africanos con el espectador y los públicos implícitos, virtuales e hipotéticos. Es por los entresijos, por los pliegues, por la autorreferencialidad del texto narrativo fílmico en sí y también por el paratexto (comentario, mensaje, prólogo, dedicatoria en los créditos de la película) por donde quisiera abordar las cuestiones ligadas a la recepción, a los modos de lectura y a los tipos de espectatorialidad previstos por algunas películas africanas contemporáneas.

Como sabemos, toda película (de ficción o documental) se refiere a su espectador, le asigna un lugar ${ }^{4}$ en el orden de la representación y del relato. $\mathrm{O}$ simplemente la película narrativa reclama la cooperación ${ }^{5}$ del espectador, de forma visible o sutil. Incluso si la interpelación ${ }^{6}$ al espectador es un proceso visible dentro de un conjunto de figuras (que la pragmática y la teoría de la enunciación ya han definido) comunes a todo el funcionamiento del lenguaje cinematográfico, en las películas africanas ${ }^{7}$, sin embargo, este proceso tiende a tomar otro aspecto en el interior del edificio de la representación (que permanece fuertemente construida sobre la opacidad del discurso fílmico, por un lado y sobre el naturalismo cuasi documental, por el otro).

Por otra parte, el estudio de la espectatorialidad que me propongo hacer en este artículo parte de dos constataciones que han acabado por imponerse como lugares comunes en las obras críticas sobre la cinematografía africana. La idea según la cual las películas africanas no llegan a su público supone, en primer lugar, que dichas películas se dirigen sobre todo a un tipo de espectador, el «espectador africano» (que habría que educar y sensibilizar a través de las imágenes y los relatos sobre África). Aunque es cierto que toda cinematografía nacional se dirige, entre otros, a un público local, me parece más aconsejable abordar esta cuestión desde el origen, es decir, a través de las estrategias narrativas que desarrolla cada película o sistema fílmico. En otras palabras, se puede examinar de otra forma la manera en la que la cinematografía africana piensa -o no- en sus espectadores, y no simplemente desde el punto de vista de una cierta intencionalidad de los cineastas.

Por otra parte, el estudio de la espectatorialidad desde una perspectiva pragmática puede chocar con una vieja problemática (o desconfianza) de origen epistemológico, a saber, si es posible o no aplicar ciertos procedimientos teórico-analíticos a las películas africanas. Por mi parte, me opongo a la idea de que las herramientas teóricas (que han sido avaladas en el estudio de una cinematografía supuestamente occidental) no sean extrapolables al estudio de la cinematografía africana. No hay que olvidar que también las películas 
africanas se construyen a través de los códigos del lenguaje cinematográfico, (que encontramos en cualquier película ${ }^{8}$ ). Por lo tanto, las películas realizadas por cineastas africanos no deberían diferir en lo relativo al alcance heurístico de estas herramientas. Todo estudio de la espectatorialidad (desde una perspectiva contextualista) se dirige por un lado a desvelar las lógicas internas del texto fílmico y por otro lado a describir las determinaciones que pesan sobre la lectura de la película en el espacio de su recepción. La elección del enfoque pragmático ${ }^{9}$ para hablar sobre la dimensión espectatorial de ciertas películas africanas se justifica por la voluntad de restringir este estudio al único contexto de las películas o categorías fílmicas, y de describir las figuras del espectador a través de una estructura enunciativa así como de la marcas metadiscursivas.

Examinaré por lo tanto ciertas películas a partir de este principio y a partir de mi propia experiencia como espectador. No se tratará de un análisis fílmico estrictamente hablando sino más bien de un estudio descriptivo de algunos segmentos y escenas fílmicos que me llevarán a poder discernir mejor la implicación espectatorial implícita en ellas. Empezaré por lo tanto por un pequeño corpus de películas africanas elegidas aleatoriamente (aunque no se trata en absoluto de películas rutinarias, como se verá más adelante) para, por una parte justificar mi tesis sobre la espectatorialidad en ciertas obras, y por otra parte, para examinar las formas peculiares que el modo de funcionamiento discursivo y pragmático del lenguaje cinematográfico adopta en la cinematografía africana. Para ello comenzaré por suponer dentro de la misma un vasto conjunto discursivo constituido por lo que hoy en día llamamos cine africano de autor $^{10}$. En esta cinematografía de la opacidad en la que vemos todo sin ver nada, que nos interpela tanto por la forma discursiva como por el contenido narrativo, las figuras del enunciador-espectador se distinguen entre líneas. Es también por la apropiación de ciertos géneros y códigos narrativos africanos que ciertos cineastas de ese continente construyen un relato fílmico que llega tanto al espectador africano como al espectador occidental. Me centraré en particular en las películas de autor cuyo relato está claramente estructurado sobre la base de la retórica del griot $^{11}$ : las películas en las que el griot aparece como un personaje narrador (en posición intra o extradiegética). Por el uso de este recurso, estas películas forman ya un sistema textual singular ${ }^{12}$. La incorporación del relato del griot al relato fílmico se presenta como un código extracinematográfico, tanto en el plano de la construcción enunciativa como en el plano de la recepción ${ }^{13}$. Como consecuencia, este sistema textual singular que llamaré de ahora en adelante "película griótica» ${ }^{14}$, presenta en el plano formal estrategias narrativas y enunciativas particulares que presuponen un modo de impli-
[8] ¿No es este acaso el principio fundador de la semiótica? A este respecto C. Metz recuerda que el análisis semiológico (narratológico y enunciativo) consiste sobre todo en preguntarse cómo una película es comprendida por el espectador (y no solamente cómo se construye).

[9] Según el enfoque pragmático del cine que ha sido formalizado por los desvíos de la teoría de la enunciación fílmica en los escritos de Metz (1991), Odin (2000), Casetti (1990) y Bettetini (1996).

[10] Aunque reconozco el carácter un tanto vago y genérico de esta expresión, interpreto aquí el cine de autor como una forma y una categoría fílmica (en oposición con el cine llamado «popular o para el gran público») y cuya existencia deriva tanto de elecciones estéticas (por parte de los autorescineastas) como de la percepción de las obras (en el espacio de la recepción critica).

[11] N. del T: el término "griot» es un africanismo de la lengua francesa que designa al narrador de historias en África occidental. Se podría traducir por bardo, trovador o cuenta-cuentos en castellano; pero dejaremos griot en el texto ya que refleja las connotaciones africanas de esta figura.

[12] Por lo menos en las cinematografías del África negra francófona y occidental.

[13] Preciso que no es la cuestión de la oralidad relativa a la figura del griot en la cinematografía africana lo que me interesa (este tema ya ha sido objeto de numerosos estudios), sino más bien las preguntas de orden teórico ligadas a la recepción y a la lectura de las películas donde la figura y el relato de este «contador de historias» crean un nivel de enunciación adicional.

[14] Concibo la «película griótica» no como un género fílmico, sino más bien como un sistema textual singular fundado en el predominio de un código narrativo extracinematográfico. 
cación del espectador y de anclaje cultural específicos. Por último, examinaré brevemente otros modos de interpelación pragmática y de construcción discursiva del sujeto espectador en las películas que entran dentro de la categoría de «cine africano de autor».

\section{Los modos de construcción del espectador en dos «películas grióticas»: Keita! L'héritage du griot y Djeli, Contes d'aujourd'hui}

La figura del espectador se percibe en la elección estética y retórica de ciertas películas africanas de poner claramente en escena al griot-narrador ${ }^{15}$. En ciertos casos, el discurso del griot se dirige siempre a un auditorio copresente en la o las escenas de la película donde aparece. De esta forma el espectador puede ver al griot cantando o declamando su texto. El espectador comparte con los personajes de la película la misma experiencia al escuchar el texto oral del griot. Entre la imagen de este auditorio en la diégesis y el espectador de la película se crea una relación de espejo, ya que ambos ocupan una relación de escucha en relación con el discurso y el relato del griot. Llamaré espectador-auditor al sujeto espectador que puedo inferir de estas películas grióticas. Por otra parte, vale la pena recordar que el relator griótico de las películas africanas no se dirige necesariamente a un público cinematográfico ordinario, más bien al contrario; por su complejidad hace intervenir a una figura de espectador cómplice, el cual, además de seguir la trama narrativa, presta una atención particular al juego formal que opera en el plano enunciativo. La voz y la imagen del griot con la que comienza el relato fílmico añaden un nuevo nivel discursivo que hace que el espectador escuche y vea a un narrador (extra)diegético que le canta y le cuenta una historia en palabras y que la película pone en imágenes. Es a partir de los intersticios de esta imbricación narrativa y enunciativa desde donde me gustaría comentar dos películas que, en mi opinión, constituyen los dos mejores ejemplos de la elección estética y retórica del griot en la construcción de un modo espectatorial particular:

[15] Existe una corriente de la cinematografía del África negra que tiende a acercar la enunciación de la representación cinematográfica a la de la literatura oral, a la tradición del cuento. Michel Serceau, «Le cinéma d'Afrique francophone face au modèle occidental: la rançon du refus» (IRIS, Revue de théorie de l'image et du son, $\mathrm{n}^{0} 18$, dossier: Nouveaux discours du cinéma africain. 1995), p. 45.
Keita! L'héritage du griot (Dani Kouyaté, 1995) y Djeli, Contes d'aujourd'hui (Kramo Lanciné Fadika, 1981).

Si Keita! L'héritage du griot y Djeli son ejemplos perfectos de lo que podemos llamar películas grióticas es porque hacen del relato oral la base de su estructura narrativa. La figura del griot aparece como el

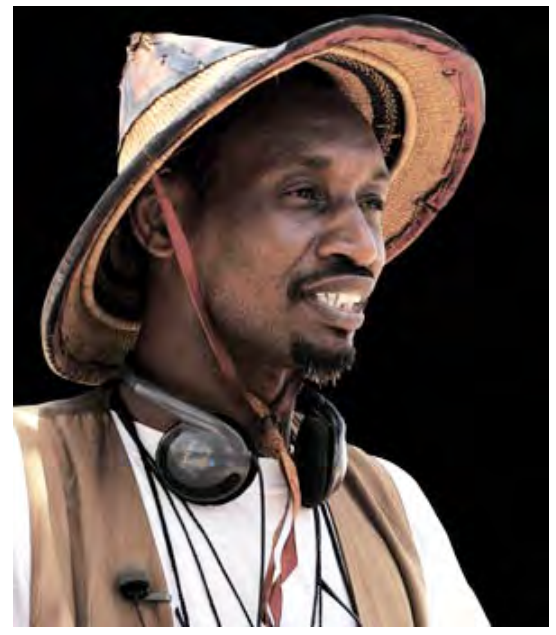

Dani Kouyaté. 
hilo conductor del relato fílmico y, por lo tanto, la descripción de su régimen espectatorial y de su dimensión pragmática es inseparable de la de su aparato enunciativo. Estas dos películas están construidas según el principio de la intertextualidad y de la intermedialidad, pero también como experiencias estéticas para el espectador; así, además de traducir y de poner en imágenes un cuento o una leyenda / fábula africanas, estas películas transportan al espectador al campo del mito y de la cosmogonía de ciertos grupos étnicos africanos. El espectador vive una doble experiencia en el plano narrativo y en el simbólico. De ahí la riqueza de la experiencia de recepción de la película griótica tanto en el plano afectivo como en el cognitivo.

\section{Fábula, leyenda y ficción en Keita! L'héritage du griot}

$\mathrm{Al}$ adaptar el mito de Soundiata al cine, el cineasta Dani Kouyaté era consciente de que se dirigía a la vez a un público africano y a un espectador no africano, y que los dos podrían vivir plenamente esta experiencia. Para transponer esta epopeya a una película, se utiliza al griot como una estrategia discursiva que interpela o llega a un espectador conocedor de la tradición oral africana y en particular, que hace descubrir esta historia del destino de un niño prodigio a un público más amplio. Puede que esta epopeya o fábula sea conocida de antemano por los espectadores que la hayan leído en la literatura africana ${ }^{16}$. Con este conocimiento previo, se puede suponer que los espectadores-lectores viven una segunda experiencia de la historia de Soundiata al ver la película Keita! L'héritage du griot (por la transposición del contenido narrativo de los griots a la novela africana y de la novela a la película). Esto mismo es válido también para un espectador africano al que su abuelo o su abuela le hubieran contado oralmente el relato de Soundiata.

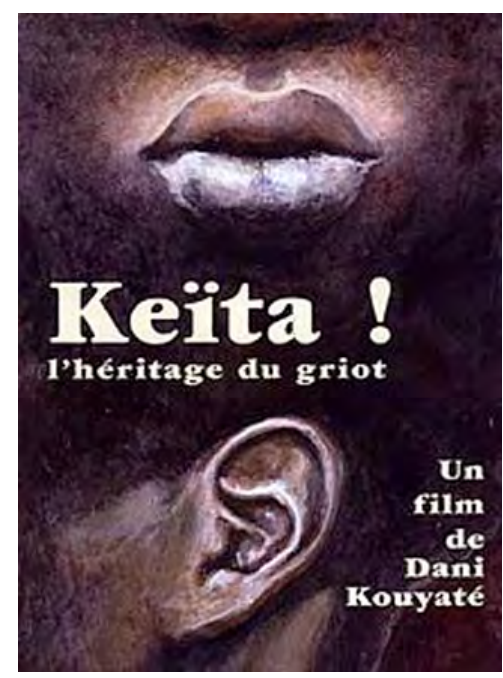

Cartel de Keita! L'heritage du griot (Dani Kouyaté, 1994).

\section{Entre fábula y leyenda}

Pasaré directamente a la descripción de la secuencia que me interesa para este análisis. Desde los primeros planos de la película, la imagen del griot Djeliba aparece en pantalla. El espectador lo ve tumbado en una hamaca. Un ligero movimiento lateral de la cámara nos lo muestra progresivamente de

[16] Djibril Tamsir Niane, Soundjata, ou l'épopée mandingue (Paris, Présence Africaine, 1971). 
[17] Entiendo aquí por fábula su significado literal en los estudios literarios: es decir, una historia imaginaria, generalmente en verso, que tiene como objetivo ilustrar una moraleja. En el ámbito del cine, Jacques Rancière nos da una definición más filosófica, más compleja y densa de la fábula cinematográfica, hasta el punto de extender su gama semántica y su aplicación a casi todas las películas (en las cuales habría una especie de «fábula discordante») y la propia teoría cinematográfica. Para Rancière, el cine es el arte de la fábula por excelencia, porque es un arte mixto, un arte con el que se puede hacer otra fábula ...

[18] Roger Odin, «La question du public: approche sémiopragmatique» (Réseaux, vol. 18, No 99, 2000), p. 59. pies a cabeza. Djeliba está inmerso en un sueño. Cuenta una historia (voz en off) que tiene tono de fábula y se remonta a tiempos inmemoriales; el mundo sale del caos:

Las tinieblas y la oscuridad del «antes de la vida» se disipaban. Wagadu era el escenario de la primera reunión de todas las criaturas del universo. En aquel tiempo, nadie mandaba a los hombres. Un hombre, Maghan Kon Fatta, se levantó y habló a los otros. El mundo no puede continuar como hasta ahora sin guía. iYo quiero ser vuestro rey! ¿Estáis de acuerdo? -iKonate!- Inmediatamente Maghan Kon Fatta tomó el nombre de Konate. Y se proclamó rey de los Mande.

Este pequeño cuento (o fábula) en off es el arranque del relato fílmico. Es lo que pone en movimiento el resto del relato. Es también un nivel de enunciación acentuado por planos panorámicos de acantilados, de travellings verticales sobre un termitero. Dado que Keita! L'héritage du griot, se construye de acuerdo a la lógica del mito y la fábula, el film permite al espectador (en el proceso de la lectura o del análisis) construir un sujeto enunciador irreal. Es esta instancia de discurso la que hace que la película funcione como una fábula cinematográfica y también como una epopeya (incluso si no recoge todos los ingredientes del género épico como ha sido consagrado en el cine de Hollywood). Este enunciador es el griot. Así como Djeliba es el personaje principal, el griot es el que empieza y otorga el punto de partida a la historia. Su voz en off se escucha desde los primeros minutos de la película. Después Keita! pone en escena a un niño pequeño en el papel de ayudante del griot. La película hace que la fascinación del espectador sea la misma que la del niño, que es el primer destinatario y oyente del mito y de la fábula que narra el griot. Pero el deseo del niño de escuchar más sobre la historia de su antepasado puede ser interpretado como una metáfora del deseo de ficción y de fábula ${ }^{17}$ por parte del espectador.

\section{El deseo de fábula y de ficción}

Al seguir la voz del griot-narrador, el espectador y el niño adoptan, cada uno en su espacio respectivo de recepción, un modo de lectura «fabulizante», actitud que, según Roger Odin, consiste en ver una película para extraer la moraleja del relato que propone ${ }^{18}$. La voz de Djeliba sumerge al niño y al espectador en las profundidades de un pasado imaginario. En efecto, una vez llegados a la ciudad y a una familia, el griot decide contarle a Mabo, el niño de la pareja, la historia de su genealogía y el origen de su apellido ilustre. A partir de este momento, se instala una relación de amistad y de complicidad entre el niño y el griot (que hace oficio de griot de la familia). Por la figura del destinatario, se puede decir que la leyenda de Soundiata en la película toma la forma de un cuento para niños. Como todo niño africano escolarizado 
en la ciudad, Mabo hace de sus libros su pasatiempo favorito. Pero a medida que comienza a deleitarse con el relato del griot, Mabo deja poco a poco de lado las novelas en beneficio de esta otra forma de relato. Djeliba es el responsable de este cambio de gustos, ya que además de ser el depositario de un «relato que puede durar toda la vida», actúa como un libro viviente. En una escena de la película, vemos a la madre de Mabo quejándose y pidiendo al griot que detenga su relato. Este último le responde: «Hija mía, no es mi culpa.

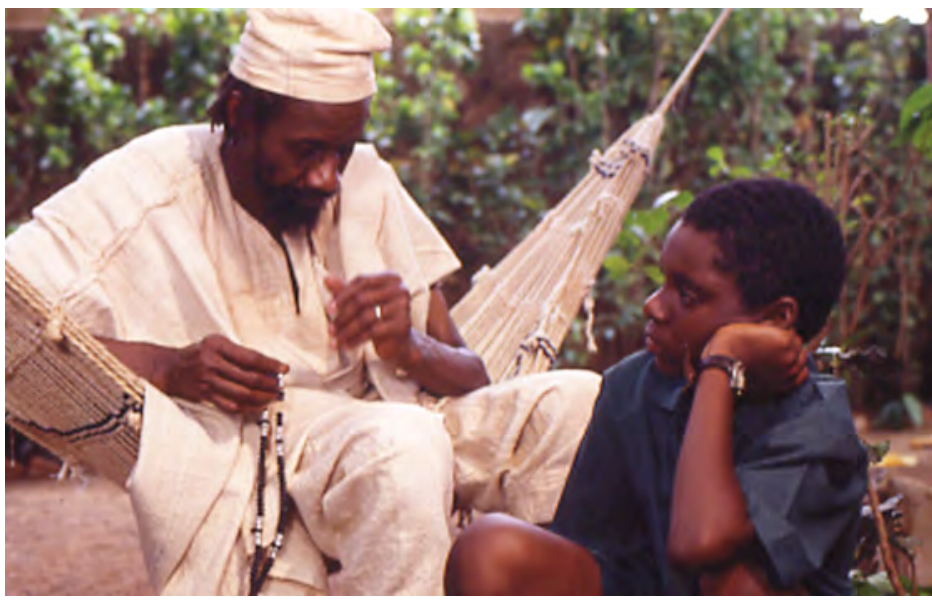

Esta historia es como el viento, no puede pararse». Como buen griot que es, Djeliba utiliza a la perfección todos los artificios de la narración de un cuento. Un cuento sin fin. Como decía Camara Laye (en su definición de la función del griot), el griot-narrador, a diferencia del historiador, no tiene más que un solo compromiso o deber; el compromiso con el lenguaje, el discurso: el de bien narrar y contar la leyenda y los cuentos de la tradición oral a aquel que le escucha. Se le juzga más por su capacidad de fabular que por su deber de contar la realidad de los hechos. Para Camara Laye, el «maestro de la palabra», es el creador de un orden discursivo en el que el valor estético del relato importa más que la veracidad del contenido narrativo ${ }^{19}$. El griot por lo tanto es un gran fabulador, un hacedor de fábulas. En Keita! es esta capacidad de fabular la que se destaca. El personaje del niño es copartícipe, de cierta forma, en la enunciación y la gestación de la historia de Soundiata (ya que es a menudo por su insistencia por lo que el griot es llevado a continuar su relato). Nosotros espectadores, ¿̇no compartimos también en el fondo la ignorancia de Mabo en la película Keita! L’héritage du griot? ¿No es acaso el espectador tradicional el que es convocado y al que se dirige la película, a través del deseo de fábula de Mabo y del relato sin fin del griot? Es decir, un espectador ávido de historias bien contadas y mil veces repetidas y reiteradas. En suma, un espectador de ficción.

Así pues, se puede aplicar a Keita! el modo de lectura fabulizante. Varios aspectos de la película permiten suponer que tal lectura es plausible. Después de todo, el espectador experimenta una fábula narrada en la ficción. Así, la primera secuencia de la película tiene el valor de una unidad discursiva y un operador narrativo que señala el principio de la ficción (y no solamente el principio de la película). Hasta se puede dividir esta secuencia inaugural de la ficción en dos grandes partes: la primera parte cuando el presentador-griot empieza su relato después de haber recibido la misión en sueños. La segunda se refiere al momento en el que el espectador lo ve prepararse para el viaje; se despide de su mujer para ir a la ciudad. Es sobre la base de estas dos partes que el espectador

Sotigui Kouyaté en Keita! L'heritage du griot (Dani Kouyaté, 1994).
[19] Camara Laye, Le Maître de la Parole: Kouma Lafôlo Kou ma (Paris, Plon, 1978), p. 21. 
diegetiza, en el sentido en que ve perfilarse un mundo sobre las imágenes figurativas. Este proceso de diegetización en Keita! se acompaña también de una impresión de realidad debido a las imágenes casi documentales de la vida en este pequeño pueblo de donde parte el griot. La película invita así al espectador a entrar en dos mundos africanos: el del campo y el de la ciudad; con todos los elementos descriptivos visuales y sonoros necesarios para la diegetización y la construcción de estos dos espacios africanos cargados de las características de la tradición y de la modernidad.

El efecto ficción, por otra parte, procede del encadenamiento de las acciones y de la partida del personaje del griot de un lugar A hacia un lugar B, así como del objetivo de este movimiento. Interviene aquí un cambio espacio-temporal. Como un héroe al que se le acaba de dar una misión, el griot se lanza hacia la ciudad con un objetivo (o un objeto) a realizar: el de transmitir la historia de Soundiata a uno de sus descendientes. Según esta lógica de la construcción narrativa de ficción clásica, hasta podemos avanzar la hipótesis de que ni el público occidental, ni el espectador africano tendrán la impresión de ver una película etnográfica o un documental sobre la tradición oral mandé. Ya que es el efecto ficción el que prevalece al final.

En lo que se refiere a la construcción del punto de vista de la historia, estamos prácticamente en el régimen de la focalización interna, ya que a lo largo de la película el espectador comparte la misma mirada, la misma sensibilidad y el mismo punto de escucha que el personaje de Mabo. La identificación espectatorial con el discurso del griot y con la opinión de Mabo se obtiene gracias a la utilización estratégica de los códigos del relato construido en cajas chinas (un relato insertado en otro; una historia en la historia) y gracias a la importancia funcional y a la recurrencia de la figura del flash back. Con todos estos métodos, la película consigue que el espectador se adhiera a la configuración ficcional que está tomando forma.

Sin embargo, es necesario recordar que el conocimiento que el espectador tiene de los hechos y la responsabilidad del relato griótico (tal como acabo de describirlos) siguen estando bajo el control del meganarrador, es decir, otra instancia del discurso desde donde es posible construir un enunciador real (algunos dirán las instancias responsables de la creación de la película, entre las cuales se encuentra naturalmente el autor-cineasta, él mismo hijo del griot). El discurso de Djeliba forma un subrelato dentro del complejo enunciativo global. De manera parsimoniosa, la película deja al relato del griot desarrollarse por pequeñas etapas, casi por pequeños episodios. Lo que supone que Mabo quiera más y vuelva a pedir. Keita! es así una experiencia fílmica y narrativa en la cual el discurso del griot, aun manteniendo un lugar importante, funciona sobre todo como una estrategia enunciativa, poética e incluso retórica que se dirige sobre todo al espectador. Por esta razón la mayoría de los análisis de esta película subrayan este aspecto formal y narratológico. Valerie Thiers-Thiam, por ejemplo, que realizó un estudio denso sobre el lugar del mito del griot-narrador en la literatura y la cinematografía africanas, ve en la 
película de Dani Kouyate una tendencia de los cineastas a apropiarse el mito del griot-narrador y a transformarlo en icono del cine africano ${ }^{20}$, ya que gracias a la manipulación de las voces narrativas, las figuras y las misiones del cineasta y el griot terminan por confundirse y asimilarse ${ }^{21}$. A fin de cuentas, el cineasta y el griot son ambos los recolectores, guardianes y testigos de las tradiciones orales y ancestrales. Para Joseph Paré, la película Keita! participa de una "estética de la recuperación» ${ }^{22}$, es decir, de un proceso de cita en el que el cineasta utiliza la estética africana tradicional (cuya materia prima es la oralidad) para construir el relato fílmico.

\section{El espectador ante dos historias en un mismo relato fílmico: Djeli, Contes d'aujourd'hui}

Las modalidades de utilización estratégicas y retóricas de la figura del griotnarrador, así como sus efectos pragmáticos en la construcción de la espectatorialidad pueden observarse en otras películas africanas y a otros niveles del tejido narrativo. Al igual que en Keita!, Djeli es una película que ofrece al espectador un cuento griótico. Como tal, se construye según la lógica de la incorporación del relato del griot en el relato fílmico, es decir, al nivel de la narración verbal y oral que se desarrolla dentro del complejo audiovisual. La película hace de la actuación, de la voz y del canto del griot su punto de partida. Por tanto, la importancia de la apertura de Djeli así como su paratexto (los títulos de crédito del final) en la instauración de la estructura enunciativa, en la constitución del régimen ficticio y en la comprensión global de la película (por el espectador) merecen algunos comentarios.

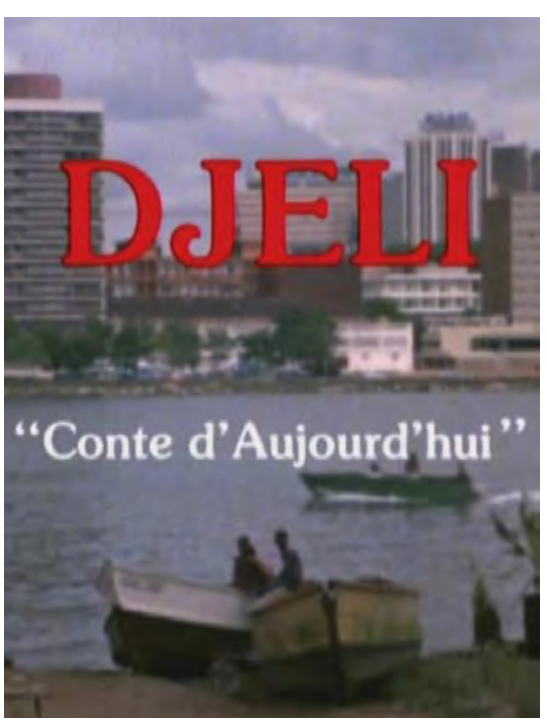

Cartel de Djeli, conte d'aujourd'hui (Kramo-Lanciné Fadika, 1981).
Los primeros planos de apertura de la película introducen al espectador en la residencia de una familia donde se ve a un griot sentado en el suelo. La escena tiene lugar en el salón. Enfrente del griot, los miembros de la familia están instalados cómodamente en un sofá y escuchan su canto y la historia que les relata. En Djeli, el griot sirve también de enlace entre el pasado y el presente. $\mathrm{Al}$ parecer, se trata de una familia de clase media que vive de manera moderna y recurre al griot para que les rememore una parte de su historia familiar y personal (eso, el espectador solo lo sabrá al final de la pelícu la). En este principio de la película, el [2o] Valérie Thiers-Thiam. $A$ chacun son griot: le mythe du griot narrateur dans la littérature et le cinéma de l'Afrique de l'Ouest (Paris: L'Harmattan, 2004).

[21] «El griot es lo que hago y el papel del cineasta en la sociedad. Es una palabra wolof que significa más que ser un simple contador de historias: el griot es un mensajero de su tiempo, un visionario y el creador del futuro» Djibril Diop Mambety, cineasta senegalés, en una entrevista con June Giavanni, en African conversations, British Films Institute/ScreenGriots, 1995. Citado por Olivier Barlet, Les cinémas d'Afrique noire: le regard en question (Paris, L'Harmattan, 1996). p. 180.

[22] Joseph Paré, «Keïta! L'héritage du griot: l'esthétique de la parole au service de l'image» (Cinémas, vol.11, $\mathrm{n}^{\mathrm{0}} 1$, automne 2000), pp. 45-59. 
[23] Recordemos que Djel trata sobre la historia de amor y matrimonio imposible de dos jóvenes estudiantes marfileños Fanta y Karamoko. La primera pertenece a una familia que, según las prohibiciones de casta de los mandinga, no puede casarse con Karamoko porque este es hijo de griot. Para señalar bien su tema sobre el conflicto entre tradición y modernidad, el cineasta Kramo-Lanciné Fadika desarrolla la trama narra tiva en dos espacios diferentes, pasando de la ciudad al campo. espectador solo ve al griot como a un personaje que narra una historia a una audiencia limitada y en un marco privado (como en el modo privado de recepción fílmica). En realidad, los hechos contados por el griot constituyen el contenido narrativo de la película. Y el espectador no tardará en darse cuenta.

En efecto, después de esta breve secuencia de apertura, el relato del griot y la película proyectan al espectador hacia un pasado lejano. Se pasa rápidamente de la escena del salón de la pareja a una escena entre los arbustos de la sabana: el espectador ve a dos hombres que caminan extenuados y muertos de hambre. No hablan. Se sientan bajo un árbol. Uno de los personajes ofrece su carne al otro, sellando así simbólicamente una suerte de pacto de sangre y carne entre dos líneas familiares. Los descendientes de estos dos personajes están desde ahora marcados por una especie de pacto o deuda simbólica. Esta escena cantada y relatada por el griot también es puesta en imágenes. Es casi un segmento aislado que se inserta al principio de la película, pero primordial para la posterior comprensión de la historia principal ${ }^{23}$. Constituye una suerte de preludio a la trama principal del film. El espectador recibe, por lo tanto, esta primera historia, dentro de la disposición general de la película, como una explicación suplementaria en su ejercicio de lectura del relato. Como se puede ver, esta información se le da por medio del canto, el relato oral y la imagen. Así pues, este segmento-preludio funciona también como una puerta de entrada del espectador en la ficción de Djeli.

\section{La entrada del espectador en la ficción de Djeli, mediante el relato del griot-narrador}

La trama principal se refiere a la historia de amor entre dos jóvenes que luchan contra el peso de las tradiciones y de las prohibiciones que les impiden casarse, ya que pertenecen a familias y a castas diferentes. Pero por el mecanismo del relato, el espectador no pondrá en relación el desenlace de esta historia con el cuento del griot hasta el final de la película. La película exige del espectador que este se acuerde de la pequeña historia del pacto de sangre y carne para completar el final de la película que parece quedar abierto. Por la misma sutileza enunciativa, la película solo permite al espectador hacer esta conexión al final. En efecto, la película se vuelve a cerrar sobre la misma secuencia de apertura (es un segmento que se repite dos veces) en la que se ve a la pareja y al griot en el salón. Pero, esta vez, el espectador ve y oye al griot que acaba su historia con una moraleja. Por un ligero movimiento de cámara, la película revela la presencia de un niño que está con la pareja, dejando entender que los dos personajes hicieron frente a las prohibiciones de la tradición y pudieron vivir su amor. En realidad, el griot les está contando una parte de su propia historia. En los créditos del final, como para hacer una referencia clara al sustrato oral y griótico de la estructura enunciativa, el realizador rinde homenaje a un griot moderno cuyo canto y música han servido de banda sonora original de la película, con estas palabras: «La música [douga] de Kouyate Sori Kandia se eligió 
para rendir homenaje al artista por su obra de rehabilitación de la música y la cultura africanas». A través de esta información lacónica, la película construye una dedicatoria al griot, que se lee también como un mensaje a su espectador. Como bien decía Genette, toda dedicatoria que parte de los márgenes del texto, del espacio del paratexto, se refiere tanto a la obra en sí, como al destinatario de la dedicatoria $\mathrm{y}$, por

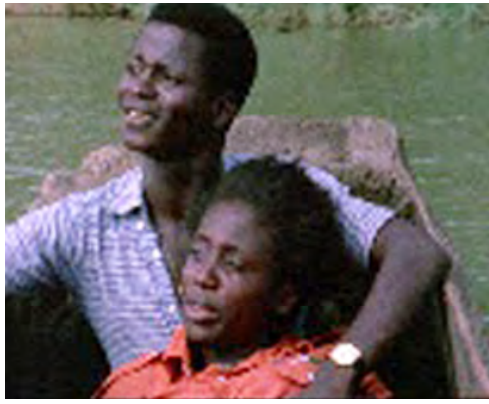

Fotograma de Djeli, conte d'aujourd'hui (Kramo-Lanciné Fadika, 1981). supuesto, al espectador que la lee y la experimenta. El efecto de la dedicatoria de Djeli hace una autorreferencia metadiscursiva a la película y define así los contornos de su dimensión pragmática, a la vez que otorga una información al espectador, a todos sus espectadores.

El tipo de espectador que puedo inferir de Keita! y de Djeli pasa por una descripción del personaje del griot-narrador (en posición intradiegética y extradiegética), guardián vivo de los mitos, de las leyendas y de la tradición oral. Desde el principio de la película, el espectador se da cuenta de que es el griot el que desempeña el papel de narrador explícito. Sin embargo, a diferencia de Keita!, el narrador-griot de Djeli se limita a empezar la historia y es dejado inmediatamente de lado. Solo reaparece al final de la película, en la escena final. El auditorio del griot en las dos películas trasciende los límites de los personajes que se ponen en escena para escuchar su historia. Keita! y Djeli se ofrecen a un público cinematográfico universal, haciendo al mismo tiempo conocer a este público la leyenda que los griots africanos tienen que transmitir. Este público no es obligatoriamente africano; no es tampoco una entidad que deba medirse por el número de entradas de las salas de cine o por las cifras de caja. Las dos películas ponen el relato del griot en imágenes y sonido. Por lo tanto lo conservan y lo dirigen a espectadores virtuales (sujetos de discurso que las propias películas construyen) y que pueden disponer de este relato oral el tiempo de un pase en una sala de cine, en un aula, en un cineclub, etc. La transposición del arte de narrar del griot al cine se fundamenta por lo tanto en una poética en el sentido aristotélico del término. Independientemente de los aspectos idiosincrásicos de las fábulas o de las leyendas de los griots puestas en escena en una película africana, estas se dirigen a un amplio auditorio, su objetivo es ante todo el gran público, más allá del público africano.

\section{La construcción del espectador en el cine africano de autor}

$\mathrm{Al}$ igual que en las películas grióticas, otras películas de autor africanas presentan en su estructura enunciativa métodos de construcción espectatorial. Siguiendo el estudio de los efectos de los gestos enunciativos y de las estrategias 
[24] Según la lógica de la semiopragmática, Roger Odin nos recuerda que es el analista el que debe construir por inferencia los modos de lectura previstos en la película (y que pueden eventualmente corresponder o no a los modos de lectura realmente puestos en marcha por el espectador en el espacio de la recepción).

[25] La noción misma de «espectador africano» (dirigida y construida por el cine africano) está también presente en el estudio narratológico que Manthia Diawara propone para las películas populares africanas y especialmente las producciones en vídeo de Nollywood (por oposición a un supuesto espectador cinéfilo occidental objetivo de las películas de autor africanas que solo son vistas en los festivales): «Solo el cine popular se toma a los espectadores africanos en serio y, por lo tanto, representa el futuro del lenguaje cinematográfico en África. Paradójicamente, a pesar de que estas películas todavía no disfrutan de los espectadores que se merecen, constituyen el verdadero comienzo del cine africano para los africanos. Los directores que podemos incluir en esta categoría, lejos de asumir que el cine es solo una actividad intelectual que alcanza su perfección y legitimidad a través de su inclusión en festivales europeos, creen que el cine debe ser sobre todo apreciado por sus propios espectadores; y el cine africano, también, por los espectadores africanos. Los espectadores africanos, que han visto películas durante los últimos cien años, ahora necesitan verse a sí mismos en la pantalla» Manthia Diawara, African Film: New Forms of Aesthetic and Politics (Munich/Berlin, Prestel Verlag, 2010), p. 145.

[26] André Gardies, Cinéma d'Afrique noire Francophone: l'espace miroir (Paris, L' Harmattan, 1989), p. 16. de interpelación, podemos decir que toda película africana se dirige a y prevé ante todo un sujeto enunciatario, es decir, un espectador textual y abstracto al que se le asigna un lugar y un recorrido ${ }^{24}$. Recordemos, sin embargo, que la hipótesis de un «espectador africano» (construido por la cinematografía africana) condujo a otros estudios espectatoriales incluyendo una perspectiva narratológica. Por ejemplo, es desde el lado del dispositivo escenográfico, del juego de identificaciones, de la construcción textual y enunciativa que André Gardies postula la figura del «espectador africano» ${ }^{25}$ (por oposición al espectador occidental). Según Gardies, lo que caracteriza a la implicación espectatorial en un gran número de películas de cine negro-africano (CNA), es el anclaje del mundo de la ficción dentro del espacio cultural del espectador. Al jugar constantemente con la similitud entre el mundo de la ficción (la diégesis) y el mundo profílmico, Gardies observa que algunos cineastas del CNA exploran en sus películas la función especular y establecen una disposición textual y una economía narrativa en las cuales se crea un «espacio-espejo». Entre las películas africanas de los años setenta y ochenta y sus espectadores se crea por lo tanto una relación singular que hace del destinatario el socio privilegiado:

Al favorecer el proceso de identificación, al jugar sobre las modalidades de enunciación y de focalización, [el cine negro africano] inscribe al espectador en un espacio de comunicación encargado de hacer de aquel un sujeto no ya «omni perceptor», sino un sujeto que todo lo ve y es omnisciente ${ }^{26}$.

Este sujeto enunciatario así construido por la película africana supone también «un espectador que se definiría por un conocimiento cultural específico (...)» ${ }^{27}$. Por lo tanto, el cine negro africano, así como su narrador-enunciador, «localiza» a su espectador modelo africano en una especie de «espacio-espejo» asignándole al mismo tiempo un lugar, invitándolo a entrar en un mundo ficticio dotado de un saber implícito. Para Gardies, podríamos imaginar y reconstituir (por inferencia), en la perspectiva de una semiótica de la recepción la figura del enunciatario (espectador) de las películas africanas por el examen de lo discursivo explícito e implícito a propósito de los códigos culturales de referencia.

En las películas africanas más contemporáneas, asistimos a otras experiencias de construcción discursiva del espectador que merecen algunos comentarios. Son películas que se construyen según la lógica del cine de autor, es decir, presentando un rigor desde el punto de vista de la puesta en escena, pero cuya dimensión comunicativa y pragmática es visible en los rastros de la enunciación, en las marcas de la metapelícula ${ }^{28}$ (que interpelan y se dirigen al sujeto

[27] André Gardies, Cinéma d'Afrique noire Francophone: l'espace miroir (Paris, L'Harmattan, 1989), p. 161.

[28] Utilizo metapelícula según el significado de este término en la teoría de la enunciación cinematográfica. Ver también la definición de metapelícula en los trabajos de poética cinematográfica de Marc Cerisuelo Hollywood à l'écran: Essai de poétique historique des films: l'exemple des métafilms américains (Paris, Presse de la Sorbonne-Nouvelle, 2000). 
enunciatario). No se trata ya de postular solamente «el espectador africano» a partir del examen de las configuraciones metafílmicas, autoreflexivas y de los paratextos de estas películas, sino más bien de ver la figura de un espectador modelo e implícito (un espectador construido y previsto por el texto fílmico). La película Les saignantes (Jean-Pierre Bekolo, 2005) nos ofrece un ejemplo perfecto de la implicación espectatorial por el comentario verbal

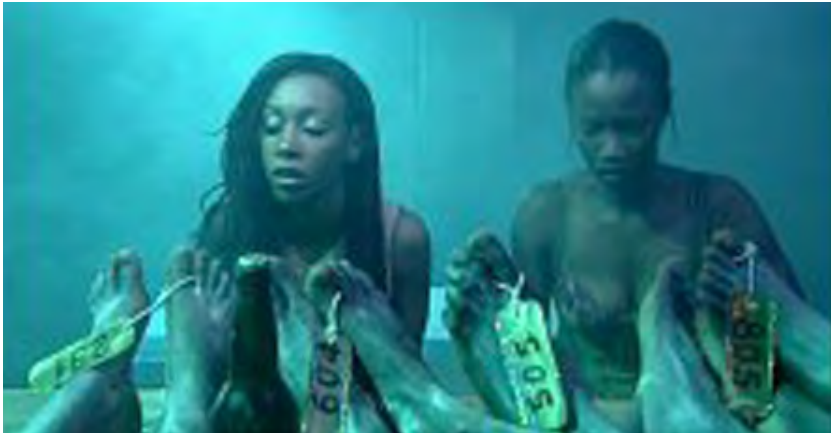

Fotograma de Les saignantes (Jean Pierre Bekolo, 2005). escrito. A primera vista, el montaje complejo y el tratamiento narrativo poco ortodoxo de esta película la vuelve poco accesible al gran público. Sin embargo, Les saignantes construye su dimensión comunicativa por medio del paratexto que aparece en la estructura de la película en forma de intertítulos. A menudo el comentario de algunas de estas menciones escritas (que encuadran las partes principales del relato) desbordan el contenido referencial de las escenas para referirse a la propia película: «¿Cómo hacer una película de amor allí donde el amor es imposible?», «¿cómo hacer una película policíaca en un país donde no se puede investigar?». O este otro intertítulo que puede leerse como un llamamiento directo dirigido al sujeto enunciatario receptor: «¿Cómo ver una película como esta y no hacer nada después?». Estos pequeños carteles tienen una función metadiscursiva ${ }^{29}$ en la medida en que producen un segundo discurso en Les saignantes. Por otra parte, aunque asumiendo la etiqueta de género para hablar de algunas de sus películas (Les saignantes es una película híbrida que puede ser definida como una película de terror, una película de amor o una película policíaca), Jean-Pierre Bekolo defiende también una idea de cine personal ${ }^{30}$ e independiente (por lo tanto un cine de autor). En consecuencia, no duda en trastocar los códigos y las normas narrativas que regulan los géneros fílmicos y el cine clásico. Sin embargo, Les saignantes tiene en cuenta a su espectador construyéndolo al mismo tiempo como receptor de un discurso en el que lo verbal contribuye a reforzar la dimensión pragmática. En Bamako de Abderrahmane Sissako (2006), por ejemplo, encontramos el mismo principio metadiscursivo en el recurso a la figura de la metapelícula: a través de un segmento separado del orden sintagmático del relato, la película desafía abiertamente a su espectador.

\section{La secuencia western de Bamako: un guiño al espectador}

Ya sabemos que Bamako, no es una película para el gran público. Es una película exigente en su forma. Y como tal, apuesta por romper con la transparencia del relato clásico. Juega con la paciencia del espectador ${ }^{31}$, comenzando por la

[29] Para Christian Metz, el espectador es el objetivo primero de todo intertítulo o comentario insertado en la película.

[3o] «Las películas clásicas te pueden enseñar cómo contar historias con un principio, un desarrollo y un final, y cómo desarrollar una trama continua, con un punto de inflexión y unas peripecias. Eso fue lo que aprendimos en la escuela de cine y a través de nuestros años de formación. Personalmente, tengo mis reservas acerca de la aceptación de estas estructuras y siempre las pongo en duda para ver si, al final, en su núcleo central, me han aportado algo». Manthia Diawara, African Film: New Forms of Aesthetic and Politics (Munich/Berlin, Prestel Verlag, 2010), p. 206.

[31] Tuve la oportunidad de asistir al estreno de Bamako en una gran sala de espectáculos con ocasión del Festival Internacional de Cine en Salvador de Bahía, Brasil. Un cuarto de los espectadores se habían ido de la sala a los treinta minutos de empezar la película. 
[32] Si los espectadores tienen buena memoria, se acordarán de las escenas de conversaciones entre los agricultores-ganaderos de un pueblo senegalés sentados bajo el baobab en el documental Kaddu Beykat/Lettre Paysanne de Safi Faye, 1975. Uno de los temas de su conversación versaba sobre los efectos del monocultivo, de la política agrícola del gobierno.

[33] Umberto Eco, Lector in fabula: le rôle du lecteur, ou la coopération interprétative dans les textes narratifs (Paris/ Grasset, 1985).

[34] El segmento autónomo (en la formalización teórica de la gran sintagmática) se define como «una parte de la película y no una parte de una parte de la película» Christian Metz, Essais sur la signification au cinéma. Vol. I. (Paris, Klincksieck, 1975), p. 125.

[35] A propósito de las relaciones de los segmentos autónomos con el resto de la película, Metz recordaba precisamente que la autonomía no es independiente en la medida en que cada uno de los segmentos solo adquiere su significado definitivo en función de la película en su conjunto (la película es considerada como «sintagma máxi mo» del cine). Christian Metz, Essais sur la signification au cinéma. Vol. I. (Paris, Klincksieck, 1975), p. 125.

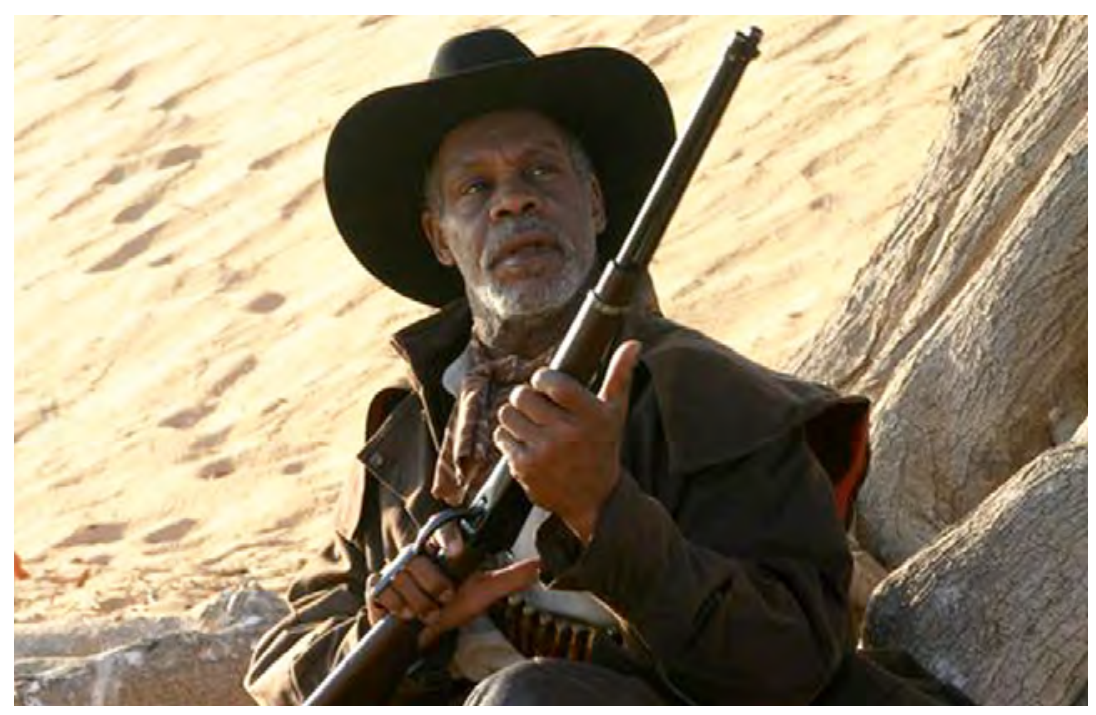

Danny Glover en la secuencia western «Death in Timbuktu» de la película Bamako (Abderrahmane Sissako, 2006)

forma en la que se construye el espacio discursivo. La articulación de los turnos de palabra (y por lo tanto de niveles de enunciación) en este tribunal improvisado en un patio comunitario (tribunal penal), recuerda el modelo de enjuiciamiento o de conversación bajo el árbol de la palabra ${ }^{32}$ en algunas tradiciones africanas. Este modelo discursivo trasladado a una película (películas de juicios) dificulta la construcción de un enunciador o de un punto de vista único (como en las películas que se ajustan a un relato clásico). Este método hace que la lectura fílmica sea difícil para el espectador ordinario. Al tomar esta decisión, la película construye y convoca a otro tipo de espectador. Un espectador cómplice que podríamos asimilar al espectador modelo ${ }^{33}$.

Pero como no pretendo inferir el espectador de Bamako del análisis global de la película, me contentaré aquí con la descripción de un segmento autónomo ${ }^{34}$ (correspondiente a una escena completa, con una unidad de sentido) que no deja a ningún espectador indiferente al visionado de la película. Aparece como salido de la nada en mitad del film y parece que el relato queda suspendido. En esta escena, que dura sus seis buenos minutos, vemos personajes vestidos de vaqueros con revólveres. Se respetan todos los códigos de vestimenta, cromáticos, de iluminación y topográficos propios al género del western. Sin embargo, el espacio (la diégesis) de esta corta película es un pueblo de la África subsahariana en Mali, en donde los habitantes son abatidos fríamente por los vaqueros como en un juego de tiro con arco.

Es un segmento que incomoda al espectador, pero que no está desprovisto de sentido. Mantiene una relación extraña con el resto de la película. A pesar de su autonomía ${ }^{35}$ en la economía narrativa de Bamako, este segmento no es completamente independiente de la película como conjunto. A la pregunta de 


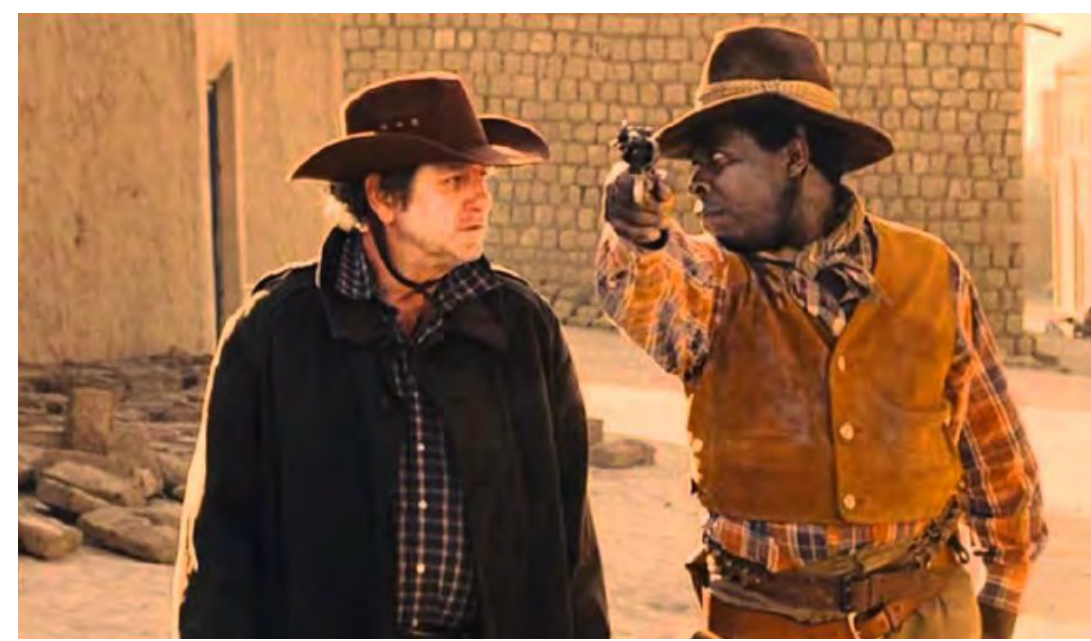

Fotograma de «Death in Timbuktu» en Bamako (Abderrahmane Sissako,, 2006)

cuál era el vínculo entre la escena de spaghetti western y el resto de la película, Sissako respondía, en una entrevista que el sentido era alegórico. Pero más allá de la connotación de esta secuencia separada del resto de la historia, lo que me interesa aquí es su funcionamiento como fragmento fílmico insertado en la estructura enunciativa global de la película. En otras palabras, ¿qué modo de lectura y a qué tipo de espectador convoca este segmento aislado dentro de Bamako?

De esta transposición de una escena de película de vaqueros a un decorado africano surge un efecto de reflexividad en forma de alusión al cine de género. Se trata efectivamente de una película dentro de la película dirigida a un público intradiegético. Este fragmento de Bamako forma una unidad discursiva plena, con un principio, una parte central y un final. Es casi un cortometraje ${ }^{36}$ que tiene sus propios títulos de crédito de apertura: «Presents... Danny Glover; Elia Suleiman; Zeka Laplaine...» y sus títulos de crédito al final donde el espectador puede leer el título en inglés «Death in Timbuktu». Los nombres están escritos en letras y caracteres tipográficos que recuerdan el estilo caligráfico de los westerns. La secuencia se le presenta al espectador de la película tras un pequeño problema técnico durante un telediario (se ve a un grupo de personas apiñadas delante de un pequeño televisor). Los jóvenes telespectadores parecen adorar la película; el espectador los ve reír. Se crea un efecto de espejo entre los personajes telespectadores de la secuencia y el espectador de Bamako. Hay pues un guiño al espectador que se reconoce así como destinatario de esta secuencia fílmica.

Los cowboys malos son también personajes conocidos en el mundo del cine (actores y cineastas). Todo cinéfilo conoce sus nombres y sus caras. El propio Abderrahmane Sissako aparece como personaje en la escena. Recordemos de paso que la irrupción del cineasta en sus propias películas se convirtió en
[36] Otros cineastas como Woody Allen o Almodóvar nos han acostumbrado a este juego de referencias metafílmico. Ver también el estudio de Marc Cerisuelo sobre los casos de metapelículas en el cine de Hollywood, desde la perspectiva que se llama de poética histórica. Marc Cerisuelo. Hollywood à l'écran: Essai de poétique historique des films: l'exemple des métafilms américains (Paris, Presse de la Sorbonne-Nouvelle, 2000) 
una especie de seña de identidad de su obra, hasta el punto de originar numerosos análisis referentes a la autorepresentación o la autobiografía en sus películas. Por mi parte, prefiero considerar esta presencia como una figura de la metalepsis ${ }^{37}$ de autor (irrupción del cineasta en la representación fílmica) según la definición de Genette, a causa, en particular, de los efectos producidos en el plano de la recepción. ¿No se refleja acaso la imagen del propio autor en su obra y en el espectador que la ve, la reconoce y la interpreta como tal? La lectura autobiográfica se deriva tanto del protocolo de producción como de los conocimientos que se movilizan en el ámbito de la recepción y de la lectura. Es sobre todo el espectador que conoce y reconoce a Sissako en esta breve secuencia el que la leerá desde una perspectiva autobiográfica.

Es pues a través de este guiño que Bamako solicita y asigna un lugar a su espectador. La metalepsis del autor así como el segmento aislado toman aquí valor de fuertes señales de la enunciación: rasgan la tela de la transparencia del discurso fílmico y dejan surgir un excedente de información que va más allá del contenido narrativo. Este excedente de información se refiere a la película como un texto con sus instancias de discurso. Estos dos fuertes signos de enunciación confieren, por otra parte, una dimensión pragmática al discurso de la película Bamako y hacen que se abra sobre su exterior, sobre su contexto, funcionando al mismo tiempo como una forma de interpelación directa y de guiño al espectador. Con su segmento aislado (en medio de la estructura de la película), Bamako solicita a la vez una participación emocional y activa por parte de su espectador. Esta tensión toma incluso la forma de una solicitud de adhesión a una complicidad entre cinéfilos que se comprenden entre sí. Aquí, es el enunciador principal de película (el cineasta) el que hace referencia a su propia cinefilia $^{38}$, transmitiendo su afición por los westerns a un espectador implícito capaz de entenderlo en este sentido.

[37] Gérard Genette, Métalepse. De la figure à la fiction (Paris: Seuil, coll. "poétique», 2004).

[38] Como sucede a menudo con el cineasta Quentin Tarantino, por ejemplo. Además de revisitar de forma lúdica el western o la blaxploitation, Tarantino afirma así su gusto por estos géneros un poco en desuso.

[39] Para Christian Metz, la figura de la película dentro de la película (que puede presentarse bajo varias formas) revela más claramente la complejidad del trabajo de enunciación en ciertos films. L'énonciation impersonnelle, ou le site du film (Paris, Méridiens Klincksieck, 1991), p. 94.

\section{Imágenes de la sala de cine, los espectadores y el cineclub: Abouna y Moi et mon Blanc}

Recordemos que hay más películas de autor africanas que están marcadas por rastros de enunciación metafílmica y de interpelaciones al espectador. Es el caso, por ejemplo, de Abouna (Mahamat-Saleh Haroun, 2002), cuando la pantalla de cine se convierte en el lugar de encuentro entre dos niños y el padre a quien habían buscado desesperadamente por toda la ciudad de Djamena ¿Sueño, delirio o realidad? Una cosa es cierta y es que en esta escena, ya antológica de la cinematografía africana, el espectador de Abouna esta confrontado a su vez a un juego de espejos al mirar a estos dos niños espectadores de otra película (la película dentro de la película ${ }^{39}$ ). Mediante la manipulación por la enunciación, la mise en abyme cobra todo su sentido. Aquí hay probablemente un sentido casi psicoanalítico de la imagen soñada del padre que se confunde con el deseo de ficción que, en un primer momento, llevó a los niños a la sala 


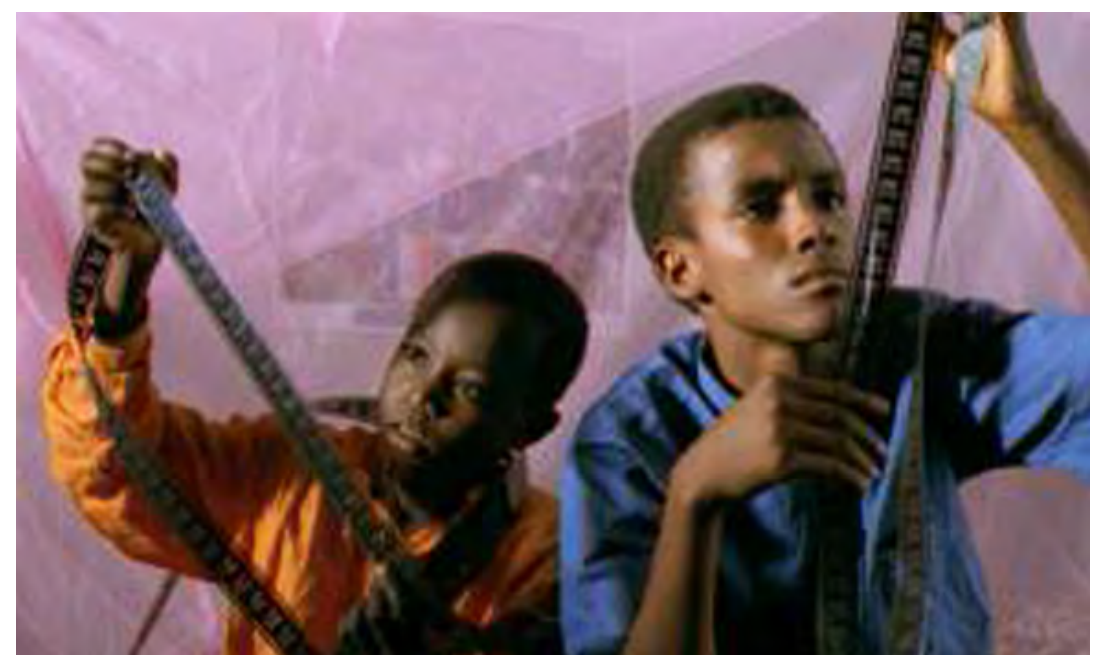

Fotograma de Abouna (Mahamat-Saleh Haroun, 2002).

de cine, antes de que uno de ellos descubra de repente la figura del padre. Van a intentar en vano extraer al padre de la banda-imagen de la película. Pero esta secuencia fílmica también se puede leer como una referencia metalingüística directa al cine, a la sala de cine como lugar institucional de recepción fílmica por excelencia (salas que tienden, desgraciadamente a desaparecer para siempre del paisaje urbano africano). En Bye Bye Africa (1999), una película anterior de Mahamat-Saleh Haroun, esta referencia directa al cine se convierte en el tema principal y en una verdadera reflexión sobre el sentido mismo de «hacer el cine» en un país en guerra y desprovisto de toda infraestructura de producción. Bye Bye Africa ofrece por lo tanto a su espectador un ensayo sobre el cine.

Encontramos el mismo proceso de redirigir al espectador a la imagen de otros espectadores de cine en Moi et mon Blanc (Pierre Yameogo, 2003). A diferencia de Abouna, Moi et mon Blanc enfrenta a su espectador a un grupo de jóvenes espectadores que no están en la sala de cine, sino en el exterior. Uno de ellos desempeña el papel de narrador al explicar la película a los otros que le escuchan. Como un narrador-griot, sus palabras se hacen imágenes. La escena es irreal y cómica, ya que tiene lugar cerca de una sala de cine y nos podemos preguntar por qué los espectadores-oyentes no entran para ver la película con sus propios ojos. La reseña de Moi et mon Blanc presenta la película como una comedia dramática y una película de aventuras. Aunque las cuestiones de la alteridad cultural y las miradas invertidas entre Francia y África sean la base temática de la película, el tono es ligero. Se trata por lo tanto de una película popular, una película de género dirigida al gran público. Una película que se dirige al espectador normal y corriente que se quiere divertir. Moi et mon Blanc parece por momentos una película de aficionados, 


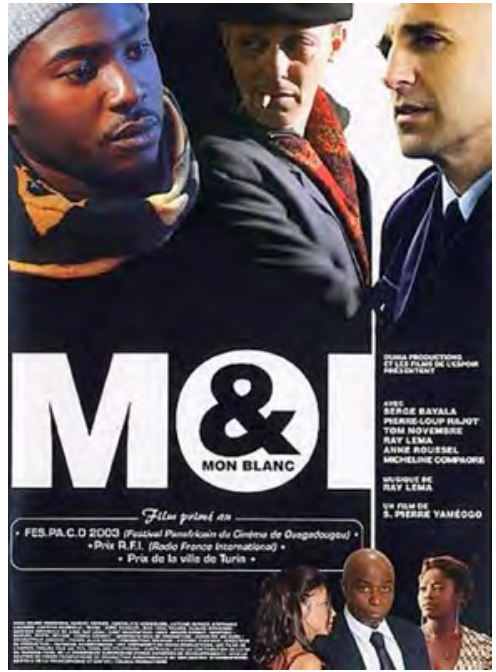

Cartel de Moi et mon blanc (S. Pierre Yameogo, 2003). sobre todo a causa de la actuación de sus protagonistas, que lo tiene todo para desagradar a un espectador cinéfilo adepto al rigor en el trabajo de escritura y en la puesta en escena. Sin embargo, la película de Pierre Yameogo demuestra una sutil manera de construir sus figuras de enunciación metafílmica: aunque es verdad que no vemos a sus espectadores en una sala de cine (sino fuera con el charlatán), sí que el director elogia a través de su película lo que podemos llamar el lugar alternativo de recepción de películas en África: el cineclub. En efecto, en la última escena de Moi et mon Blanc el espectador ve a un grupo de niños y adolescentes agrupados alrededor de

un televisor y un magnetoscopio. Asisten, entre risas y aplausos, a una película de vaqueros. La última escena de la película nos deja ver y oír un divertido debate entre dos niños de este cineclub que provoca la sonrisa o la risa en todo espectador.

\section{La interpelación directa al espectador a través del paratexto $4^{\circ}$ de los títulos de crédito.}

Como acabamos de ver, las referencias al espectador son numerosas en la cinematografía africana. En la ficción, las imágenes de espectadores se convierten en estrategias para la construcción del esquema narrativo y enunciativo. Pero otras películas africanas prefieren dirigirse directamente al espectador por métodos de interpelación en el paratexto fílmico, es decir, desde los títulos de crédito de principio o de final de la película. En Djeli, por ejemplo la palabra «Habana» (en lengua malinké) sustituye a las tradicionales letras de «FIN». Como si el enunciador o el autor supusieran que la película había sido vista por un público africano que comprende el sentido de esta palabra. Pero es también una manera de señalar el anclaje cultural y lingüístico de la película. El pequeño texto explicativo que aparece en el prólogo en los títulos de crédito del principio de Sarraouina (Med Hondo, 1986) es también una especie de men-

[40] Entiendo aquí paratexto tal y como ha sido definido por Gérard Genette en sus dos libros Seuils (Paris, Seuil, 2002) y Palimpsestes (Paris, Seuil, 1992) y más tarde aplicado al campo del cine. saje dirigido a un espectador africano y no africano, al que se le sitúa en el contexto histórico y colonial de la historia de Sarraounia (la película es una adaptación de una obra literaria). Se le prepara, así, para adentrarse en este drama épico y bélico en el que se mezclan la voluntad de reconstitución histórica y la venganza sobre la historia. La palabra final en los títulos de crédito de Teza 
(Haile Gerima, 2008) toma, al contrario, la forma de una dedicatoria: «Esta película está dedicada: a mi madre Mulu Basilious y mi hermana Elsa Gerima. A todas las personas de raza negra que han sido golpeadas y asesinadas solo por ser negras; y a un sinnúmero de jóvenes etíopes que fueron asesinados por atreverse a traer un cambio sincero a Etiopía.». Con estas pocas palabras, Teza se dirige a un público específico: los espectadores etíopes, africanos, negros americanos y los espectadores de las diásporas que se reconocen respectivamente en la dedicatoria del final de la película. Como vemos, los títulos de crédito de todas estas películas africanas (y muchas más) forman fragmentos de un metadiscurso (hablan de la película), pero a través de estos fragmentos el enunciador cineasta se dirige directamente y sin artificios retóricos a un espectador que es a la vez implícito e hipotético.

\section{Conclusión}

Si los estudios narratológicos de cine hablan de la universalidad de los relatos, es por un lado, porque parten de la hipótesis de que todo espectador está dotado de una habilidad o de una intuición particular que le permite descifrar todo texto narrativo. El relato, como lo definía bien Barthes ${ }^{41}$, comienza por la historia de la humanidad (al menos, tal y como cada pueblo la concibe, la construye y la cuenta a sus miembros). Así, todos los grupos humanos tienen sus propios relatos. Pero con frecuencia estos relatos también se construyen, se comparten y se aprecian con otros seres humanos pertenecientes a culturas diferentes. Las películas africanas comparten, a su manera, esta característica. En lo referente a los enfoques pragmáticos del cine, parten de la idea de que toda película «se hace para ser vista» señalando así de una forma u otra la presencia del sujeto al que se dirige ${ }^{42}$. La dimensión espectatorial se revela, entre otras cosas, por una serie de rastros de enunciación. Es, por lo tanto, en la confluencia de estos dos enfoques sobre la «comunicación cinematográfica» (que toma forma bajo el relato en la ficción) donde me he situado para examinar los métodos de inscripción de las figuras del espectador implícito en la estructura enunciativa de algunas películas africanas. En líneas generales, lo que he propuesto en este artículo, consiste en desplazar la pregunta de los públicos de la cinematografía africana al terreno teórico de la recepción cinematográfica. Como hemos visto, tal planteamiento teórico exige inevitablemente la construcción de la instancia espectatorial dentro de las propias películas.

Por una parte, al seguir la estética de la recuperación y la apropiación del discurso del griot por cineastas africanos, he intentado problematizar el tipo de implicación espectatorial que se observa en la categoría fílmica de lo que he llamado "película griótica» (en el seno de un cierto tipo de cine de autor africano). Esta utilización del griot convoca, pues, entre los públicos africanos y no africanos, posturas y modos de lectura fílmicos particulares que solo pode-
[41] Roland Barthes (org.), Análise estrutural da narrativa (Petrópolis, RJ: Vozes, 2008).

[42] Francesco Casetti. D'un regard l'autre: le film et son spectateur (Lyon, Presses Universitaires, 1990), p. 12. 
mos delimitar y examinar a través del texto cinematográfico, desde una perspectiva textual y semiopragmática. Ante una película griótica, podríamos incluso inferir otros modos de lectura además de la ficcionalización y la fabulización. Pienso por ejemplo, en el modo estético que deliberadamente he omitido mencionar aquí. El espectador puede hacer intervenir al modo estético en la medida en que puede observar una película griótica desde el punto de vista de la combinación de la imagen fílmica con el canto y la actuación musical del griot, por ejemplo. Algunos espectadores cinéfilos o un teórico de los cines africanos podrán practicar este modo de lectura. Pienso, por ejemplo, en el cortometraje de Ousmane Sembène Niaye (1964), en el cual un griot cuenta las consecuencias del embarazo de una joven en una comunidad de Senegal. Lo que capta la atención del espectador es que los comentarios del griot intervienen en voz en off y que esta voz es completada por la de una mujer. Las dos voces (masculina y femenina) se relevan en el relato de esta historia. Algunos espectadores se darán cuenta de este juego de entrecruzamiento de voces en esta pequeña película griótica y movilizaran un modo de lectura estética de la misma. Aunque mi análisis se ha centrado en las películas grióticas, hemos visto que existen otras películas africanas, en el registro de la ficción, que constituyen casos interesantes que merecen también ser estudiados. Por otra parte, en cuanto a la reflexividad que observamos en el discurso de películas como Les saignantes y Bamako, podemos suponer que hacen alusión a rasgos del cine moderno. En efecto, si existe una tendencia en el cine moderno ${ }^{43}$ en el ámbito de la cinematografía africana, esta puede verse en las películas de autor, en la negación de los códigos normales de la construcción narrativa. En definitiva, esta dimensión metadiscursiva termina por significar una forma de implicación espectatorial sutil, ya que el espectador ve en este redoblamiento del discurso un guiño. En ese caso, las configuraciones metafílmicas que puntúan el tejido enunciativo (así como las interpelaciones directas en los títulos de crédito y en el paratexto) valen como interpelaciones directas e indirectas al sujeto enunciatario-espectador.

En resumen, los regímenes espectatoriales desplegados en las películas africanas que he examinado aquí tienen en común el deseo de dirigirse a un espectador hipotético (si consideramos la cuestión desde el punto de vista del espacio de la recepción, este espectador puede ser africano u occidental, cinéfilo, de la diáspora, etc.) por medio de pequeñas estrategias de interpelación y alusión. Siguiendo esta lógica de lectura, se podría concluir que existe una preocupación por el público en la cinematografía africana; se puede inferir tal preocupación teniendo en cuenta el proceso de transformación del público en sujeto espectador del texto fílmico. Es el análisis textual y contextual el que nos permite medir todo el alcance pragmático, y simbólico de tal postulado.

[43] Un cine moderno que prefiere la opacidad a la trasparencia del discurso del relato.

Traducción del francés: María Valenzuela 


\section{BIBLIOGRAFÍA}

BARLET, Olivier. Les cinémas d'Afrique noire: le regard en question (Paris, L'Harmat$\tan , 1996)$.

BARTHES, Roland (org.) Análise estrutural da narrativa (Petrópolis, RJ: Vozes, 2008)

Bettetini, Gianfranco. La conversación audiovisual (Madrid, Cátedra, Signo e Imagen, 1996)

CASETTI, Francesco. D'un regard l'autre, le film et son spectateur (Lyon, Presses Universitaires, 1990)

Cerisuelo, Marc. Hollywood à l'écran: Essai de poétique historique des films: l'exemple des métafilms américains (Paris, Presse de la Sorbonne-Nouvelle, 2000)

Diawara, Manthia. African Film: New Forms of Aesthetic and Politics(Munich/Berlin, Prestel Verlag, 2010)

Diop, Cheikh Anta. Nations nègres et culture (Paris, Présence Africaine, 1954)

Eco, Umberto. Lector in fábula: le rôle du lecteur, ou la coopération interprétative dans les textes narratifs (Paris, Grasset, 1985)

GARDIES, André. Cinéma d'Afrique noire Francophone: l'espace miroir (Paris, L'Harmattan, 1989)

GaUdreault, André; JOST, François. A narrativa cinematográfica (Brasília, UNB, 2009)

GenetTE, Gérard. Palimpsestes (Paris, Seuil, 1992)

-, Seuils (Paris, Seuil, 2002)

-, Métalepse. De la figure à la fiction (Paris, Seuil, coll. «poétique», 2004)

LAYE, Camara. Le Maître de la Parole: Kouma Lafôlo Kouma (Paris, Plon, 1978)

METZ, Christian. Essais sur la signification au cinéma. Tome I. (Paris, Klincksieck, 1975)

-, L'énonciation impersonnelle, ou le site du film (Paris, Méridiens Klincksieck, 1991)

Odin, Roger. «La question du public: approche sémio-pragmatique» (Réseaux, vol. 18, No 99, 2000).

PARÉ, Joseph, «Keïta! L'héritage du griot: l'esthétique de la parole au service de l'image» (Cinémas, vol.11, $\mathrm{n}^{\mathrm{0}}$ 1, automne 2000), p. 45-59.

SERCEAU, Michel. «Le cinéma d'Afrique francophone face au modèle occidental: la rançon du refus» (IRIS, Revue de théorie de l'image et du son, $\mathrm{n}^{0} 18$, dossier: Nouveaux discours du cinéma africain. 1995), p. 39-45.

THIERs-Thiam, Valérie. À chacun son griot: le mythe du griot-narrateur dans la littérature et le cinéma de l'Afrique de l'Ouest (Paris, L'Harmattan, 2004). 